\title{
EFFECTS OF MULBERRY HEARTWOOD INFUSION ON T-BUTOOH -INDUCED EXPRESSION OF PROINFLAMMATORY GENES IN MACROPHAGE CELL CULTURE
}

\author{
Milena Pasheva, Milka Nashar, Oskan Tasinov, Neshe Nazifova-Tasinova, Diana Ivanova \\ Department of Biochemistry, Molecular Medicine and Nutrigenomics, \\ Faculty of Pharmacy, Medical University of Varna
}

\begin{abstract}
Oxidative stress is a key factor in the induction of chronic inflammation by activation of a variety of transcription factors and proinflammatory cytokines, which in turn could mediate different chronic pathological conditions. In the present study Morus nigra heartwood ethanol infusion was applied to oxidatively stimulated macrophage cells with the aim to investigate the effect of the plant on the expression of genes involved in proinflammatory response. The infusion markedly reduced the mRNA levels of the nuclear factor kB (NF-kB), tumor necrosis factor alpha (TNF- $\alpha$ ) and interleukin-1 $\beta$ (IL-1 $\beta$ ) in a concentration-dependent manner. These results are a new contribution to the knowledge about the therapeutic potential of the mulberry tree, especially about its poorly examined heartwood.
\end{abstract}

Keywords: Morus nigra, heartwood infusion, oxidative stress, macrophages, gene expression

\section{INTRODUCTION}

Oxidative stress and inflammation are closely related phenomena, contributing to pathological conditions, such as cardiovascular diseases, metabolic syndrome and diabetes (15). Reactive oxygen species (ROS) may have a major impact on redox-sensitive signaling pathways in different types of cells, including macrophages and adipocytes $(1,13,20)$. The

Address for correspondence:

Milena Pasheva

Department of Biochemistry, Molecular Medicine and

Nutrigenomics

Medical University of Varna

84 Tzar Osvoboditel Blv.

9002 Varna, Bulgaria

e-mail:pasheva19@gmail.com

Received: May 1, 2016

Accepted: June 5, 2016 activation of redox-sensitive transcription factors, such as NF- $\kappa B$ is a prerequisite of the induction of proinflammatory gene expression, including tumor necrosis factor alpha (TNF- $\alpha)$ and interleukin-1 $\beta$ (IL-1 $)(4,11,24,39)$.

Understanding the mechanisms behind the beneficial effects of medicinal and edible plants is the scope of many scientific investigations. It is known that plant extracts and plant phenolic compounds are able to modulate the production and function of cytokines and thus could be an alternative for inflammatory diseases counteraction $(5,10)$.

Morus nigra L. (mulberry tree) is an arboreal plant traditionally applied by the folk medicine because of the various healing effects of its fruits, leaves and root bark $(6,17,33)$. Along with the knowledge about the medicinal properties of the plant, mulberry is known to also have other traditional application - its heartwood is used as a material for barrels man- 
ufactured for storage of alcoholic beverages and respectively for their aging. Although, the ethanol extracts of mulberry heartwood have specified phytochemical composition (12), to our knowledge their biological effects still remain unrevealed. In our previous study, we estimated that the ethanol infusion from mulberry heartwood inhibited the expression of NF- $\kappa \mathrm{B}$ and TNF- $\alpha$ in a model of oxidative stress in preadipocyte cell culture and we speculated about the effects of mulberry on adipose tissue metabolism and related diseases (22).

Now, the aim of this study is to explore the effect of ethanol infusion from Morus nigra heartwood on the expression of proinflammatory cytokines in oxidatively challenged macrophages, types of cells that are directly involved in low-grade inflammation of the fat tissue and associated metabolic diseases.

\section{MATERIALS AND METHODS \\ Infusion Preparation}

Ethanol infusion from Morus nigra heartwood a humidified chamber containing $5 \% \mathrm{CO}_{2}$. Nutrient medium comprised of phenol red-containing Dulbecco's modified Eagle's medium (DMEM, Lonza) with 4,5g/L glucose, L-glutamine and supplemented with fetal bovine serum (FBS) to a final concentration of $10 \%$ and penicillin/streptomycin mixture to a final concentration of $100 \mathrm{U} / \mathrm{ml}$ each. Cells were grown in cell culture flasks up to $80 \%$ confluence.

\section{Experimental Procedure}

The macrophages were collected and seeded in 6 well flasks at density $2 \times 10^{5}$ cells/well for different treatments (Table 1). The Morus nigra infusion (M) or $40 \% \mathrm{EtOOH}(\mathrm{Et})$ was dissolved as follows: $6.25 \mu \mathrm{l}$, $12.5 \mu \mathrm{l}$ or $25 \mu \mathrm{l}$ to $2 \mathrm{ml}$ in phenol red- free DMEM to a final content in the nutrient medium of $0.3 \%, 0.6 \%$ and $1.25 \%$, respectively.

For an induction of oxidative stress, cells were treated for 24 hours with $100 \mu \mathrm{M}$ tertiary-butylhydroperoxide (t-ButOOH, tB) (32). At the end of the treatment the cells were collected for total RNA extraction.

Table 1. Treatment groups of J774A.1 macrophages

\begin{tabular}{lcc|c|}
\hline \multirow{2}{*}{ Compound } & $\begin{array}{c}\text { Final content in the nutrient } \\
\text { medium }(\%)\end{array}$ & Groups \\
\cline { 2 - 4 } & 0.3 & Mithout oxidant & with oxidant \\
$40 \%$ ethanol infusion from M.nigra (M) & 0.6 & M 0.6 & M 0.3+tB \\
& 1.25 & M 1.25 & M $1.25+\mathrm{tB}$ \\
$40 \%$ ethanol (Et) & 0.3 & Et 0.3 & Et $0.3+\mathrm{tB}$ \\
& 0.6 & Et 0.6 & Et $0.6+\mathrm{tB}$ \\
& 1.25 & Et 1.25 & Et $1.25+\mathrm{tB}$ \\
\hline
\end{tabular}

was prepared following the traditional recipe for coloring high alcoholic beverages: $2 \mathrm{~g}$ dried material from heartwood were placed in $1 \mathrm{~L} 40 \%$ ethanol for 40 days. Heartwood samples were subjected to fumigation following the popular technology for aging of beverages: the wooden chips were boiled for 10 minutes and then saturated with cold water for 24 hours. Finally, the material was dried for 15 minutes at $150-190^{\circ} \mathrm{C}$.

\section{Cell Culture}

Mouse J774A.1 macrophages were obtained from American Type Culture Collection (ATCC). The cells were cultured in $75 \mathrm{~cm}^{2}$ flasks at $37^{\circ} \mathrm{C}$ in

\section{Quantitative Real-Time PCR Analysis}

Total RNA was extracted from J774A.1 macrophages using TRI Reagent according to the manufacturer's protocol (Ambion). In order to remove the contamination of genomic DNA, DNA-ase I treatment was performed using the recommended protocol of the manufacturer (Sigma). Complementary DNA was synthesized using Revertaid ${ }^{\mathrm{TM}}$ First Strand Synthesis Kit with oligo (dT) $)_{18}$ primers and RevertAid $^{\mathrm{Tm}}$ reverse transcriptase (Thermo Scientific). The synthesis reaction was performed on GeneAmp PCR System 9700 (Applied Biosystems). Two-step realtime PCR analysis was performed (ABI PRISM 7500, 
Milena Pasheva, Milka Nashar, Oskan Tasinov et al.

Applied Biosystems) to estimate gene expression level in cultured cells. Maxima SYBR Green qPCR Kit (Thermo Scientific) was used for sample analysis. The cDNA was amplified using forward and reverse primers of target genes (Table 2) commercially synthesized (Invitrogen Alpha DNA, Canada). Beta-actin was used as endogenous control. All samples were analyzed in triplicates. Gene expression levels were calculated by a $2^{-\Delta \Delta \mathrm{Ct}}$ method (18) and expressed as relative units (RU) mRNA compared to the untreated controls where the level of gene expression of interest was considered to be equal to 1 .
As demonstrated in Figures 1, 2 and 3, the addition of the oxidant to the nutrition medium (group tB) resulted in a significant increase in mRNA levels of the three tested genes, as compared with the controls ( ${ }^{* * *} \mathrm{p}<0.001$ vs. group C). Furthermore, a cumulative effect of ethanol and the oxidant was observed in stimulation of the expression of all three genes for the groups Et1.25+tB.

\section{Expression of NF- $k B$}

Real-Time qPCR analyses demonstrated that none of the applied concentrations of the mulberry infusion changed the NF-kB expression (Fig. 1).

Table 2. Sequences of primers used for RT-PCR analysis
Genes Nucleotide sequence
$\beta$-Actin F: 5'-ACG GCC AGG TCA TCA CTA TTG-3'
$\beta$-Actin R: 5'-CAA GAA GGA AGG CTG GAA AAG- 3'
NF-kB F: 5'-ATGGCAGACGATGATCCCTAC- 3'
R: 5'- TGTTGACAGTGGTATTTCTGGTG- 3'
TNFa
F: 5' CCCTCACACTCAGATCATCTTCT -3'
R: 5'- GCTACGACGTGGGCTACAG -3'
IL-1 $\beta$
F: 5' TTCAGGCAGGCAGTATCACTC- -3
R: 5'- CCACGGGAAAGACACAGGTAG -3'

\section{Statistical Analysis}

Data are presented as mean \pm standard error of mean (SEM). Differences between the means of the groups were analyzed by Student's $t$-test or one-way ANOVA with Dunnett's multiple comparison test (GraphPad Prism 5.0). Values of $\mathrm{P}<0.05$ were considered to be statistically significant.

\section{RESULTS}

\section{Effects of the Oxidant on Gene Expression}

The toxicity of t-ButOOH includes lipid peroxidation, depletion of cellular storage of glutathione and DNA damage $(16,19,27)$. Its intracellular metabolism may cause mitochondrial oxidative stress (38).

In the present study t-ButOOH was applied in macrophage cell culture with the purpose of provoking oxidative stress. Three concentrations of mulberry ethanol infusion were applied to explore the effect of the preparation on genes related to the inflammatory response. The same concentrations of ethanol or ethanol along with the oxidant were applied in order to distinguish the effects of the plant-derived active compounds from the effects of ethanol solely.
Ethanol applied alone stimulated the expression of the gene in a concentration-dependent manner $\left({ }^{* *} \mathrm{p}<0.01\right)$. Pretreatment with the infusion (groups M0.6+tB and M1.25+tB) decreased significantly ox-

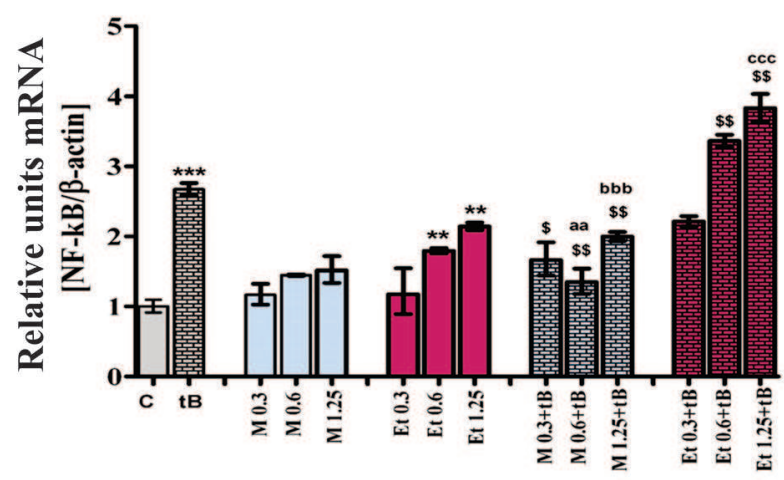

Figure 1. Expression of NF- $k B$ in J774A.1 macrophages, treated with different concentrations of $M$. nigra heartwood ethanol infusion in normal medium or under $t$-ButOOH-induced oxidative stress. Data are presented as mean \pm standard eror of mean (SEM); ${ }^{* * *} p<0.001$, ${ }^{* *} p<0.01$ vs. group $C ;{ }^{\$ \$} p<0.01$ vs.groups $t B ;{ }^{a a} p<0.01$ vs.group $E$ t $0.6+t B ;{ }^{b b b} p<0.001$ vs.group Et $1.25+t B$ 
idant-induced gene expression of NF-kB $\left({ }^{\$} \mathrm{p}<0.01\right)$. Furthermore, this inhibitory effect was confirmed in comparison with the cells treated with the same concentration of ethanol with the oxidant (Et0.6+tB and Et1.25+tB). Moreover, the ethanol and the oxidant applied together had a cumulative stimulatory effect on the mRNA levels of the gene.

\section{Expression of TNFa}

Figure 2 summarizes the effects of the mulberry heartwood ethanol infusion on the TNF- $\alpha$ gene expression. The three applied concentrations of the infusion did not change the mRNA levels of the cytokine. Ethanol applied alone in concentrations 0.6 and 1.25 significantly stimulated the expression of the gene $\left({ }^{* *} \mathrm{p}<0.01\right)$. All of the applied concentrations of the infusion significantly inhibited the expression of TNF- $\alpha$ as compared with the tB treated cells ${ }^{\left({ }^{\$} \mathrm{p}<0.01\right)}$ upon induction of oxidative stress (groups $\mathrm{M}+\mathrm{tB}$ ). Furthermore, the highest concentration of the infusion, applied in the oxidatively stimulated cells significantly inhibited the expression of the cytokine as compared to the ethanol+oxidant treated cells ( ${ }^{\mathrm{cc}} \mathrm{p}<0.01$ vs. Et $\left.1.25+\mathrm{tB}\right)$.

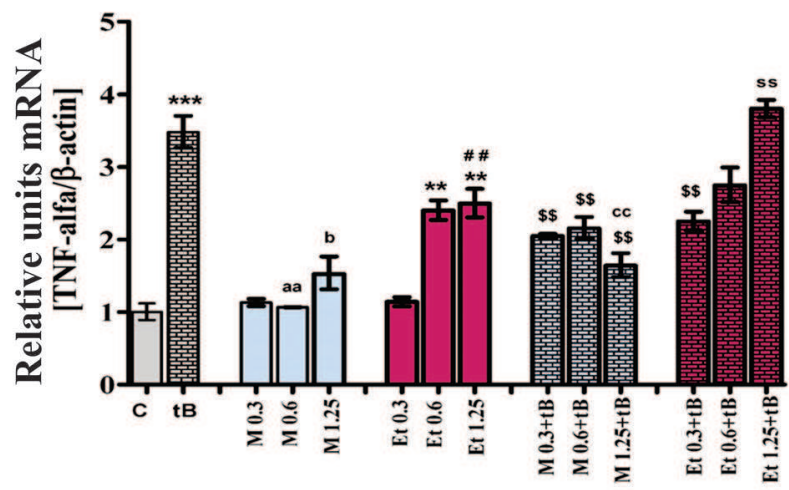

Figure 2. Expression of TNF $\alpha$ in J774A.1 macrophages, treated with different concentrations of $M$. nigra heartwood ethanol infusion in normal medium or under $t$-ButOOH induced oxidative stress. Data are presented as mean \pm standard eror of mean (SEM); ${ }^{* *} p<0.001$ and ${ }^{* *} p<0.01$ vs. group $C ;{ }^{\$} p<0.01$ vs. groups $t B ;{ }^{a a} p<0.01$ vs. group Et $0.6 ;{ }^{b} p<0.05$ vs. group Et $1.25 ;{ }^{c c} p<0.01$ vs. group Et $1.25+t B{ }^{s s} p<0.01$ vs. group Et $0.3+t B ;{ }^{\# \#} p<0.01$ vs. group Et 0.3

\section{Expression of IL-1 $\beta$}

The two higher concentrations of the mulberry infusion significantly inhibited the expression of
IL- $1 \beta$, compared with the controls ${ }^{* *} \mathrm{p}<0.01$ for M0.6 and ${ }^{*} \mathrm{p}<0.05$ for M1.25 versus group C). On the other hand, the ethanol applied alone in a concentration of 1.25 (group Et 1.25) significantly stimulated the cytokine expression $\left({ }^{*} \mathrm{p}<0.05\right)$. Pretreatment with the two higher concentrations of the mulberry infusion (groups $\mathrm{M} 0.6+\mathrm{tB}$ and $\mathrm{M} 1.25+\mathrm{tB}$ ) decreased significantly $\mathrm{t}$-ButOOH - induced gene expression of IL$1 \beta\left({ }^{\$} \mathrm{p}<0.05\right.$ and ${ }^{\$ \$ \$} \mathrm{p}<0.001$ versus group $\left.\mathrm{tB}\right)$. Data are presented in Figure 3.

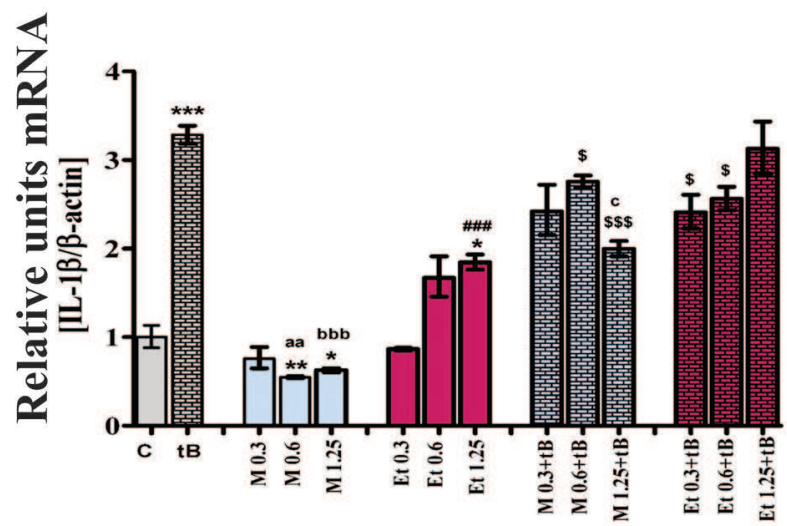

Figure 3. Expression of IL-1 $\beta$ in J774A.1 macrophages, treated with different concentrations of $M$. nigra heartwood ethanol infusion in normal medium or under $t$ ButOOH-induced oxidative stress. Data are presented as mean \pm standard eror of mean (SEM); ${ }^{* *} p<0.001$, ${ }^{* *} p<0.01$ and ${ }^{*} p<0.05$ vs. group $C ;{ }^{\$ \$} p<0.001$ and ${ }^{\$} p<0.05$ vs. groups $t B ;{ }^{a a} p<0.01$ vs. group Et $0.6 ;{ }^{b b b} p<0.001$ vs. group Et 1.25; ${ }^{c} p<0.05$ vs. group Et $1.25+t B ;{ }^{\# \#} p<0.001$ vs. group Et 0.3

\section{DISCUSSION}

The aim of the study was to explore the potential of mulberry heartwood ethanol infusion to affect the expression of three genes involved in the inflammatory response in a model of oxidative stress. Scientific data point that ROS could play a crucial role as intermediates in the development of chronic inflammation (21). Several studies reported that the impairment of redox balance in the cells could be related to induced expression of proinflammatory factors $(13,26)$. The heterodimeric protein NF-kB is a redox-sensitive transcriptional factor involved in immune and inflammatory response, cell proliferation and apoptosis (7). Its activity could be affected by ROS in different ways (21). The target genes acti- 
Milena Pasheva, Milka Nashar, Oskan Tasinov et al.

vated by NF-kB encode the synthesis of various cytokines, including TNFa, cytokines and their receptors as well as cell adhesion molecules (9). As a crucial factor involved in inflammatory responses, the activity of NF-kB is associated with both aging process and age-related diseases, for example, cancer, obesity, diabetes and atherosclerosis (2).

The results obtained in this study showed that mulberry infusion applied under conditions of oxidative stress (groups $\mathrm{M}+\mathrm{tB}$ ), markedly inhibited the expression of the three genes. Moreover, a pronounced concentration dependency was estimated in this effect. In a recent study, similar effect of the infusion on the expression of NF-kB and TNFa was observed in an oxidatively stimulated preadipocyte cell culture (22).

The described effects could be attributed to the active compounds extracted in the solution from the plant. Previously, we estimated that the mulberry heartwood infusion possessed high antioxidant activity in vitro, correlating with high total polyphenol content (23). Many authors reported similar effects of the polyphenols or polyphenol-rich extracts on the proinflammatory cytokines (including TNFa) in various experimental models of oxidative stress and inflammation $(28,37)$. As potent antioxidants, polyphenols can affect the function of nuclear factor-erythroid 2-related factor 2 (NRF2) and AMPK signaling pathways. Polyphenols can also directly repress NF-kB signaling (29).

TNFa, a proinflammatory cytokine involved in the pathogenesis of many chronic diseases, could provide the link between inflammation and the development of insulin resistance (3). The mechanisms which connect the increased production of ROS, inflammation and obesity involve increased production of proinflammatory cytokines from macrophages such as TNFa and IL-1 $\beta$ (30).

IL- $1 \beta$ is produced by macrophages and it is responsible for the acute phase of inflammation (14). Several studies reported that polyphenols and polyphenol-rich extracts had the potential to inhibit both, the IL-1 $\beta$-stimulated expression of NF-KB and directly the expression of pro-inflammatory cytokines, such as TNFa, IL-1 $\beta$ and IL- 6 in cell cultures $(8,34)$. Proinflammatory cytokines produced by macrophages are implicated in the pathogenesis of meta- bolic disorders such as metabolic syndrome and insulin resistance (35). The infiltration of TNFa, IL-1 $\beta$ and IL- 6 could play a role of a paracrine stimulus, activating NF-kB signaling pathway and thus increasing the systemic levels of cytokines in adipocytes observed in overweight subjects $(25,31)$. On the other hand, naturally derived inhibitors of the NF-kB are considered to be a promising approach for the prophylaxis and management of pathological conditions that are due to prolonged activation of this signal pathway (36).

\section{CONCLUSION}

The results reported in this study are another small step in clarifying the biological activities and therapeutic potential of Morus nigra heartwood infusion. Its antioxidant and anti-inflammatory action observed in models of induced oxidative stress indicate that this preparation from the plant could be a potential source of active ingredients applicable for prevention and treatment of various chronic diseases.

\section{Aknowledgements}

This study was supported by the "Science" Fund of Medical University of Varna, Grant 14013/2015).

\section{REFERENCES}

1. Anderson M. T., Staal F. J. T., Gitler C., Herzenberg L. A., and A. Herzenberg L., "Separation of oxidant-initiated and redox-regulated steps in the NF- $\kappa B$ signal transduction pathway," Proceedings of the National Academy of Sciences of the United States of America, vol. 91, no. 24, pp. 11527-11531, 1994.

2. Baker, R.G., M.S. Hayden, S. Ghosh, 2011. NF-kB, inflammation, and metabolic disease. Cell Metab., $13,11-22$.

3. Bastard, J.P., M. Maachi, C. Lagathu, M. J. Kim, M. Caron, H. Vidal, J. Capeau, B. Feve, 2006. Resent advances in the relationship between obesity, inflammation and insulin resistance. Eur Cytokine Netw., 17,(1), 4-12.

4. Brown DM, Hutchison L, Donaldson K, MacKenzie SJ, Dick CA, Stone V. The effect of oxidative stress on macrophages and lung epithelial cells: the role of phosphodiesterases 1 and 4 . Toxicol Lett. 2007 Jan 10;168(1):1-6. Epub 2006 Nov 6.

5. Calixto JB., Campos MM., Otuki MF., S. Santos AR. Anti-Inflammatory compounds of plant ori- 
Effects of Mulberry Heartwood Infusion on T-Butooh -Induced Expression of Proinflammatory Genes in Macrophage Cell ...

gin. Part II. Modulation of pro-inflammatory cytokines, chemokines and adhesion molecules. Planta Med 2004; 70(2): 93-103.

6. Chan K.C, M.Y. Yang, M.C.Lin, Y.J. Lee, W.C. Chang, C.J. Wang, 2013. Mulberry leaf extract inhibits the development of atherosclerosis in cholesterol- fed rabbits and in cultured aortic vascular smooth muscle cells. J Agric Food Chem., 61(11):2780-2788.

7. Chen L.F. and Greene W.C. Shaping the nuclear action of NF-kappaB. Nat.Rev.Mol.Cell Biol. 5, 39240, 2004.

8. Cho J.Y., Kim P.S., Park J., Yoo E.S., Baik K.U., Kim Y.K., Park M.H.,2000. Inhibitor of tumor necrosis factor-alpha production in lipopolysaccharidestimulated RAW264.7 cells from Amorpha fruticosa., Journal of Ethnopharmacology, 70, 127-33.

9. Collins T, Cybulsky MI. NF-kappaB: pivotal mediator or innocent bystander in atherogenesis? J Clin Invest. 2001;107(3):255-64.

10. Comalada M, Ballester I., Bailon E., Sierra S., Xaus J., Galvez J., de Medina F.S., Zarzuelo A., 2006. Inhibition of pro-inflammatory markers in primary bone marrow-derived mouse macrophages by naturally occurring flavonoids: analysis of the structure-activity relationship. Biochem Pharmacol, 72,1010-21.

11. Csiszar A., Wang M., Lakatta EG. and Ungvari Z., 2008. Inflammation and endothelial dysfunction during aging: role of NF-KB. J Appl Physiol , 105, 1333-1341

12. De Rosso M.D., D. Cancian, A. Panighe A.D. Vedova, R. Flamini, 2009. Chemical compounds released from five different woods used to make barrels for aging wines and spirits: volatile compounds and polyphenols. Wood Sci Tech., 43, 375-385

13. Haddad J. Redox regulation of pro-inflammatory cytokines and I $\mathrm{B} / \mathrm{NF}-\kappa \mathrm{B}$ nuclear translocation and activation. Biochem. Biophys. Res. Commun., 296 (2002), pp. 847-856

14. Haseeb, A., C. Dongxing T. M. Haqqi, 2013. Delphinidin inhibits IL-1b-induced activation of NFiB by modulating the phosphorylation of IRAK-1 Ser376 in human articular chondrocytes. Oxford University Press.,258-269.

15. Houstis, N., E.D. Rosen and E.S. Lander, 2006. Reactive oxy-gen species have a causal role in multiple forms of insulin resistance. Nature 440, 944-948.
16. Kučera O., Endlicher R., Roušar T., Lotková H., Garnol T., Drahota Z, and Červinková Z., 2014. The effect of tert-butyl hydroperoxide-induced oxidative stress on lean and steatotic rat hepatocytes in vitro. Oxid Med Cell Longev. Article ID 752506, 12 pages

17. Kumar A, P.K.Chauhan, V.S.Bhardwaj, R. Kumar, A.Tyagi, 2011. In vitro antioxidant and phytochemical investigations of ethanolic extracts of Viola serpens and Morus nigra. J Chem Pharm Res.,3(4),166-171.

18. Livak, K. J., T.D. Schmittgen, 2001. Analysis of relative gene expression data using real-time quantitative PCR and the 2- $\Delta \Delta \mathrm{C}(\mathrm{t})$ method. Methods, 25 (4), 402-408.

19. Martín C, Martínez R, Navarro R, Ruiz-Sanz JI, Lacort M, Ruiz-Larrea M.B., 2001. tert-Butyl hydroperoxide-induced lipid signaling in hepatocytes: involvement of glutathione and free radicals. Biochem Pharmacol. Sep 15;62(6):705-12.

20. Mohora M, Greabu M., Totan A., Mitrea N., Battino M., 2009. Redox-sensitive signaling factors and antioxidants. FARMACIA 57(4), 399-411.

21. Morgan MJ and Liu ZG. Crosstalk of reactive oxygen species and NF- $\kappa$ B signaling. Cell Res. 2011(1): 103-115.

22. Pasheva, M., Nashar, M., Ivanova, D.P., Tasinov O.,Ivanova D.I., 2015. Effects of mulberry heartwood extract on the gene expression of NF-kB and two proinflammatory cytokines in a cell culture model of oxidative stress. Science \& Technologies, vol.V, Number 1, Medicine, pp.47-54

23. Pasheva, M., M. Nashar, D. Pavlov, S. Slavova, D. Ivanov, D. Ivanova, 2013. Antioxidant capacity of different woods traditionally used for coloring hard alco-holic beverages in Bulgaria.-J. Sci. Technol., 3, (1), 123-127.

24. Pavlović D., Đorđević V., Kocić G. 2002. A “crosstalk" between oxidative stress and redox cell signaling. FACTA UNIVERSITATIS, Series: Medicine and Biology Vol.9, No 2, 2002, pp. 131 - 137.

25. Permana, P.A,. C.Menge, P.D.,2003. Reaven: Macrophage-secreted factors induce adipocyte inflammation and insulin resistance. Bio-chem Biophys Res Commun, 341, 507-514.

26. Reuter S., Gupta SC., Chaturvedi M. Aggarwal B. Oxidative stress, inflammation, and cancer: How are they linked? Free Radic Biol Med. 2010; 49(11), 1603-1616. 
Milena Pasheva, Milka Nashar, Oskan Tasinov et al.

27. Roy A., Sil P.C. 2012. Tertiary butyl hydroperoxide induced oxidative damage in mice erythrocytes: Protection by taurine. Pathophysiology 19 (2), 137-148.

28. Sabu M.C., Kuttan R., 2002. Anti-diabetic activity of medicinal plants and its relationship with their antioxidant property. J Ethnopharmacol 81,155-1

29. Salminen A, Kauppinen A, Kaarniranta K., 2012. Phytochemicals suppress nuclear factor- $\kappa \mathrm{B}$ signaling: impact on health span and the aging process. Curr Opin Clin Nutr Metab Care. 15(1),23-8.

30. Sell, H., J. Eckel, 2010. Adipose tissue inflammation: novel insight into the role of macrophages and lymphocytes. Curr Opin Clin Nutr Metab Care, 13, $366-370$.

31. Suganami, T., J. Nishida, Y. Ogawa, 2005. A paracrine loopbetween adi-pocytes and macrophages aggravates inflammatorychanges: role of free fatty acids and tumor necrosis factoralpha. Arterioscler Thromb Vasc Biol., 25, 2062-2068.

32. Tasinov O., Kiselova-Kaneva Y., Ivanova D., 2013. Sambucus ebulus L. fruit aqueous infusion modulates GCL and GPx4 gene expression. Bulg J Agricult Sci 19 (2), 143-146.

33. Venkatesh K.R., S. Chauhan, 2008.Mulberry: Life enhancer. J Med Plants Res., 2(10), 271-278.

34. Wheeler, D.B., Bailey, S.N., Guertin, D.A., Carpenter, A.E., Higgins, C.O., Sabatini, D.M. (2004) RNAi living-cell microarrays for loss-of-function screens in Drosophila melanogaster cells. Nat. Methods 1(2), 127-132.

35. Xu H, Barnes GT, Yang Q, Tan G, Yang D, Chou CJ, 2003. Chronic inflammation in fat plays a crucial role in the development of obesity-related insulin resistance. J Clin Invest, 112 (12), 1821-30.

36. Yamamoto Y, Gaynor RB. Therapeutic potential of inhibition of the NF-kappaB pathway in the treatment of inflammation and cancer. 2001. J Clin Invest.;107(2):135-42.

37. Yen GC, Chen YC, Chang WT, Hsu CL., 2011. Effects of polyphenolic compounds on tumor necrosis factor- $\alpha$ (TNF- $\alpha$ )-induced changes of adipokines and oxidative stress in 3T3-L1 adipocytes. J Agric Food Chem 59(2):546-51

38. Zavodnik IB, Dremza IK, Cheshchevik VT, Lapshina EA, Zamaraewa M. Oxidative damage of rat liver mitochondria during exposure to t-butyl hydroperoxide. Role of $\mathrm{Ca}^{2+}$ ions in oxidative processes. Life Sci. 92(23):1110-7, 2013.
39. Zhang X, Wang G, Gurley E.C., Zhou H.,2014 Flavonoid Apigenin Inhibits Lipopolysaccharide-Induced Inflammatory Response through Multiple Mechanisms in Macrophages. PLoS ONE 9(9): e107072. doi:10.1371. 